Portland State University

PDXScholar

\title{
Values Mapping and Counter-Mapping in Contested Landscapes: an Olympic Peninsula (USA) Case Study
}

\author{
Rebecca J. McLain \\ Portland State University, mclainrj@pdx.edu \\ Lee Cerveny \\ US Forest Service Pacific Northwest Research Station \\ Kelly Biedenweg \\ Oregon State University \\ David Banis \\ Portland State University, dbanis@pdx.edu
}

Follow this and additional works at: https://pdxscholar.library.pdx.edu/geog_fac

Part of the Physical and Environmental Geography Commons, and the Sustainability Commons Let us know how access to this document benefits you.

\section{Citation Details}

McLain, R., Cerveny, L., Biedenweg, K., \& Banis, D. (2017). Values mapping and counter-mapping in contested landscapes: an Olympic Peninsula (USA) case study. Human Ecology, 1-16.

This Article is brought to you for free and open access. It has been accepted for inclusion in Geography Faculty Publications and Presentations by an authorized administrator of PDXScholar. Please contact us if we can make this document more accessible: pdxscholar@pdx.edu. 


\title{
Values Mapping and Counter-Mapping in Contested Landscapes: an Olympic Peninsula (USA) Case Study
}

\author{
Rebecca McLain ${ }^{1}$ (D) $\cdot$ Lee Cerveny $^{2} \cdot$ Kelly Biedenweg $^{3} \cdot$ David Banis $^{4}$
}

Published online: 31 August 2017

(C) US Government (outside the USA) 2017

\begin{abstract}
Indigenous peoples, local communities, and other groups can use counter-mapping to make land claims, identify areas of desired access, or convey cultural values that diverge from the dominant paradigm. While sometimes created independently, counter-maps also can be formulated during public participation mapping events sponsored by natural resource planning agencies. Public participation mapping elicits values, uses, and meanings of landscapes from diverse stakeholders, yet individuals and advocacy groups can use the mapping process as an opportunity to make visible strongly held values and viewpoints. We present three cases from the Olympic Peninsula in Washington State to illustrate how stakeholders intentionally used landscape-values mapping workshops to amplify their perspectives in attempts to further political outcomes. We combine geospatial analysis with qualitative data to explore ways that landscape-values mapping were used as a political tool and how social scientists engaged in similar efforts can defend the scientific integrity of results.
\end{abstract}

Keywords Counter-mapping · PPGIS · Landscape values · Public participation $\cdot$ Place identity $\cdot$ Olympic Penninsula, USA

Rebecca McLain

rebeccamclain@gmail.com

1 Institute for Sustainable Solutions, Portland State University, Portland, OR 97201, USA

2 US Forest Service, Pacific Northwest Research Station, Seattle, WA 98103, USA

3 Department of Fisheries \& Wildlife, Oregon State University, Corvallis, OR 97331-3803, USA

4 Department of Geography, Portland State University, Portland, OR 97201, USA

\section{Introduction}

Landscape-values mapping is a public engagement approach that can produce data for identifying points of conflict or convergence among values associated with particular locations (Brown and Reed 2009). Through inviting the public to map places that are important to them, landscape-values mapping studies, which are a type of public participation geographic information systems (PPGIS), have shed light on energy-generation location preferences (Pocewicz and Nielsen-Pincus 2013), forest values (Brown and Reed 2009), and community use zones (RamirezGomez et al. 2016), among other issues. However, rarely do these analyses include descriptions of on-going political debates over land and natural resource that might influence who chooses to map, what values they map, and how they map. Yet maps inevitably describe politicized perspectives of the places they represent (Harley 1989; Wood 2009).

We draw on the ideas of place theorists and critical cartographers to explore how tensions over the ownership and management of federally managed lands in the northwestern United States influenced the Olympic Peninsula Human Ecology Mapping (HEM) project results. The HEM project was a landscape-values mapping project implemented in 2010 and 2011 in western Washington (Fig. 1) to test the usefulness of community mapping workshops as a landscape-values data collection method (Besser et al. 2014; McLain et al. 2013a). The project collected baseline data on values associated with the Olympic Peninsula landscape, but the way in which the mapping process unfolded suggests that some of the participants saw the workshops as an opportunity to voice dissent over proposed land management changes. Although we were aware of existing tensions over land management in the region, we did not anticipate the orchestrated nature of counter-mapping that occurred in two of the workshops. We used a combination of density analyses of the spatial data and frequency analyses of the non-spatial data to 
Fig. 1 Olympic Peninsula with workshop locations. Color figure available online

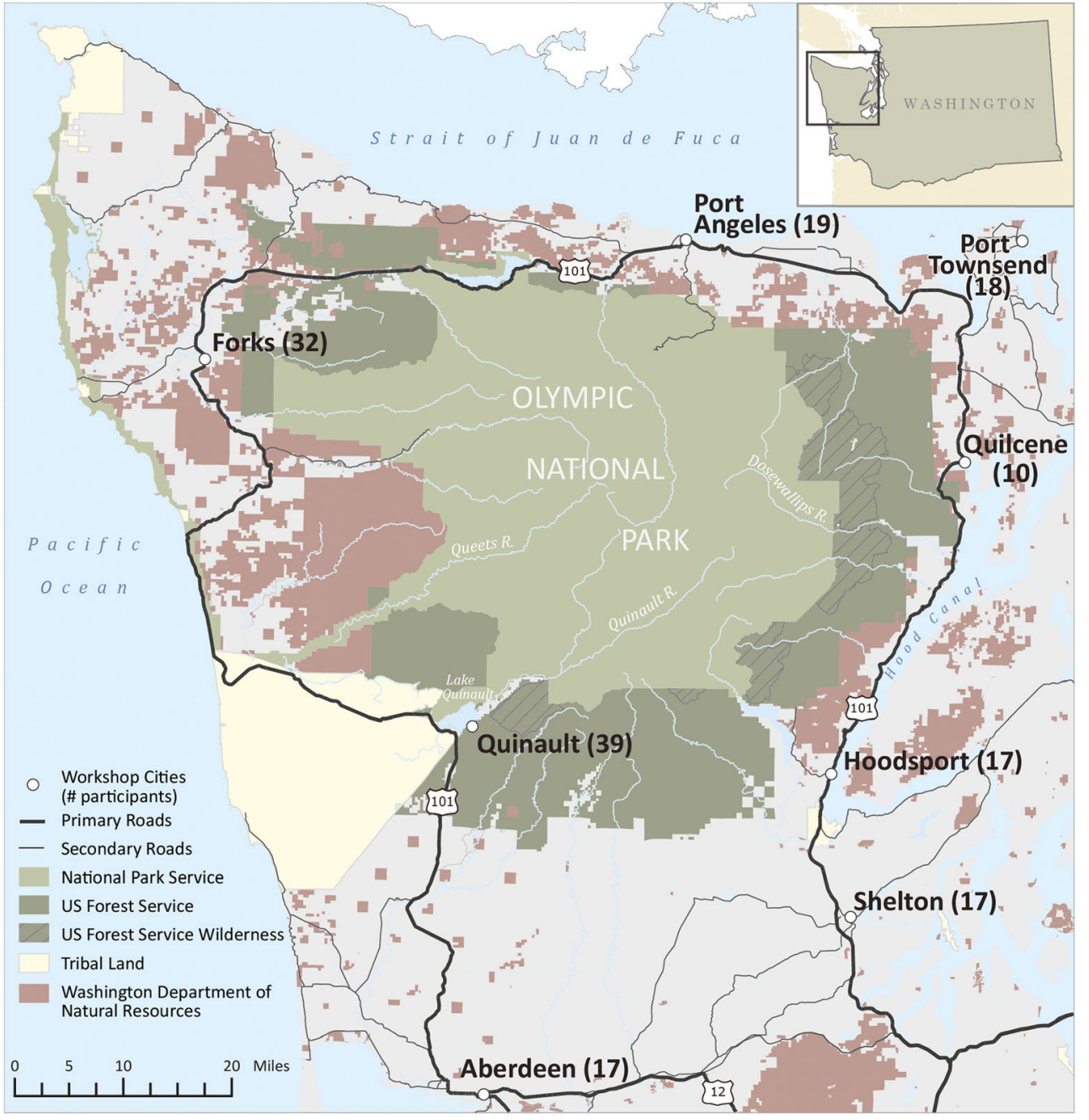

examine the proposition that participants may sometimes use landscape-values mapping collectively to articulate perceived claims to land and other resources and their visions for how those resources should be managed. Our study foregrounds the inherently political nature of landscape-values mapping, and serves as a reminder that participants often have agendas that differ substantially from researchers' and land managers' intended purposes.

\section{Melding the Politics of Place with Critical Cartography}

Place theory offers one explanation for the often-intense debates associated with land management. Places are more than physical locations on landscapes, they are social constructions derived from individual and group values to undifferentiated space (Tuan 1977). Associating meanings with places enables us to make sense of the world and may provide the motivations for taking protective actions of a particular location (Sack 1992). When attachments to place are particularly strong, those places may become part of individual and cultural identities (Proshansky et al. 1983; Twigger-Ross and
Uzell 1996), and changes to places can trigger very strong emotions (Devine-Wright 2009). Such interventions can spark political action (Devine-Wright 2009; Hurley and Walker 2004) and in some cases, violent conflict as individuals and groups seek to preserve identities entangled with particular senses of place (Cheng et al. 2003).

In creating and maintaining place, individuals and groups engage in what Kemmis (1990) referred to as the politics of place, or activities that foster their visions of what places should look like, the types of activities that are acceptable, and who belongs in that place (Yung et al. 2003; Cheng et al. 2003). Language and other forms of discourse play a central role in the politics of place, with a variety of symbols and narratives used to support or resist claims to place (Stokowski 2002). For example, during the late 1990s, environmental activists in Australia cast logging as a crime against nature that threatened pristine landscapes and sacred spaces (Twigger 1999). Forest industry spokesmen, on the other hand, made appeals to the importance of meeting community needs by protecting livelihoods. Similar discourses threaded through the rhetoric associated with the timber wars in the Pacific Northwest (Proctor 1995) 
and the Wise Use Movement in the American West during the 1990s (Hurley and Walker 2004; Walker and Fortmann 2003).

The use of discursive strategies in the politics of place draws attention to the need to examine how maps and mapmaking are used in contests over place meanings. Harley (1989:11) argues that scientific cartography not only reflects power relations, but is an "inherently rhetorical discourse" that nation-states and other social actors use to control people, land, and resources. What is included on a map affects who has access to land and resources (Peluso 1995), whose ecological knowledge is considered legitimate (Rundstrom 1990), and how costs and benefits of environmental decisions are distributed (Bethel et al. 2011). Wood (1992) argues that maps are graphic arguments that emerge from social processes and reflect and project the interests of those who create them. Equally reflective of power relations are the "silences" of maps (Harley 2009:290), as maps "exert a social influence through their omissions as much as by the features they depict and emphasize." The silences of maps not only influence social relations but they also transform the biophysical environment by shaping which species and landscapes get protected and which do not (Carolan 2009; Harris and Hazen 2006). Understanding the story behind the map, including the political dynamics of the mapping process, is therefore an important aspect of map interpretation (Perkins 2003).

Peluso (1995) used the term "counter-mapping" to describe the use of maps produced by indigenous peoples in Indonesia to "pose alternatives to the languages and images of power" present on territorial maps produced by the national government. She argued that counter-maps "greatly increase the power of people living in a mapped area to control representations of themselves and their claims to resources" (Peluso 1995:387). Indigenous peoples and rural communities in many parts of the world have used counter-mapping to assert claims to land and resources (Chapin et al. 2005). Wood's (2009) discussion of counter-mapping examples in post-industrial societies, however, makes clear that countermapping occurs the world over.

In the Pacific Northwest region of the United States, the site of our case study, The Wilderness Society created a counter-map during 1989-1990 depicting the remaining areas of old growth forests in the region (Norheim 2001). This map was constructed as an alternative to the old growth map that the U.S. Forest Service produced at the same time. The two maps used the same definition of old growth, the same source data, and similar data analysis technologies. Yet, the Forest Service map showed 1.5 million ha of old growth remaining compared with The Wilderness Society's 0.8 million ha. Neither map was ever adequately ground-truthed, but the very existence of The Wilderness Society's counter-map was sufficient to undermine the legitimacy of the U.S. Forest Service's old growth map (Norheim 2001). The counter-map helped accelerate policy reforms during the 1990s that favored forest protection over commercial timber harvest on federally managed forests in the Pacific Northwest (Norheim 2001).

\section{Landscape-Values Mapping}

The Olympic Peninsula HEM project is one of dozens of projects that have sought to develop and test methods for integrating spatially explicit landscape-values in environmental planning (Brown and Kyätta 2014; McLain et al. 2013b). Terms used to describe these projects include landscapevalues mapping (Brown 2005), community values mapping (Raymond 2009), public participation GIS (Brown and Reed 2009), and place attachment mapping (Gunderson and Watson 2007). Following Brown (2005) we use the term landscapevalues mapping (LVM). Landscape-values consist of individual perceptions of what is meaningful about particular geographical locations, and mapping these values using public input improves understandings of whether values overlap and if so, whether they are compatible or in conflict with each other. Public participation in LVM studies runs the gamut from asking survey respondents to assign values based on a pre-defined list of values (e.g., Brown 2005; Sherrouse et al. 2011) to highly participatory projects in which community members contribute substantively to all phases of mapping and analysis (e.g., Biedenweg et al. 2014; Ramirez-Gomez et al. 2013; Tipa and Nelson 2008).

A few researchers have reflected on the politics associated with the LVM process. In a mapping project in Suriname (Ramirez-Gomez et al. 2013), some villagers saw the maps as tools for asserting use rights to proposed conservation reserves; others believed that the maps would help further formal recognition of their traditional rights. Participants in several villages engaged in what Ramirez-Gomez et al. (2013:20) describe as strategic mapping, which they define as mapping "to identify places and attributes that [participants] believe will lead to desired outcomes in future land use". Brown et al. (2014) also encountered strategic mapping in a web-based values mapping study in northern California that compared volunteered data on values and development preferences with data solicited through a random sample survey. Volunteer responses emphasized utilitarian forest values, such as timber harvesting and off-road vehicle riding, whereas the random sample responses emphasized protection oriented values. They concluded: "individuals with stronger forest utilization preferences [i.e., the volunteer group] mobilized for volunteer participation in the study" (Brown et al. 2014:20), but did not provide details on that mobilization process. These examples mesh with critical geographers' argument that maps are socially constructed tools used to persuade others that the reality they depict is valid (Harley 2009; Wood 2009). We expand upon these examples by making the politics of values mapping the main focus of our case study. Analyses of the resource politics that influence such projects are important because map users are likely to base their 
interpretation of the patterns visible on the maps entirely on what they see, rather than seeking to understand the politics that may have shaped those patterns.

We explore three examples of counter-mapping that vary in terms of scale and degree of coordination. The first, "Fighting wilderness expansion," describes an orchestrated attempt by opponents of proposed legislation expanding wilderness areas on the Olympic Peninsula to use the workshops to depict the strength and extent of participants' livelihood connections with local forests. The second, "Defending motorized recreation," describes an example where motorized recreational vehicle advocates encouraged supporters to participate in a workshop close to an area that the U.S. Forest Service was considering for an off-highway vehicle (OHV) use area. The third, "Dosewallips road closure," represents a contentious situation on the Olympic Peninsula since 2002, when a major road providing access to the eastern part of the Olympic National Park was washed out five miles short of several heavily-used trailheads and campgrounds. Unlike the other two cases, however, no management decision or legislation was imminent for the road closure project.

\section{Study Site}

The three case studies took place on the Olympic Peninsula in northwestern Washington (Fig. 1). The peninsula is dominated by the Olympic Mountains, a series of glaciated peaks rising from sea level to nearly $2400 \mathrm{~m}$. Nearly half of the Olympic Peninsula is in public ownership. Federally managed lands include the Olympic National Park (ONP) (3700 sq. km) and the Olympic National Forest (ONF) (2500 sq. km), which abuts the park on three sides (Headwaters Economics 2012). The outermost ring of the Olympic Peninsula is divided into Washington State Trust Land (1940 sq. km), tribal land (1005 sq. km), and privately owned land (7420 sq. km) (Headwaters Economics 2012). The four counties encompassing the peninsula have a combined population of 235,000 (US Census 2010) and a land area of $16,580 \mathrm{sq}$. $\mathrm{km}$. The population is unevenly distributed with most inhabitants residing in larger towns located along the peninsula's northern, eastern, and southern edges. The peninsula's western edge and center are sparsely populated with large areas completely devoid of settlements.

Much of the peninsula was logged during the latenineteenth and twentieth century, with the more accessible and productive forests along the western and southern flanks of the Olympics experiencing multiple harvest rotations (Dark 1997; Dietrich 1992). Only the ONP and the more inaccessible portions of the ONF have large areas of late successional forests remaining. During the past 20 years, the Olympic Peninsula's economy has shifted from being dominated by the forest products, fisheries, and agricultural sectors toward a services dominated economy (Buttolph et al. 2006). Major demographic changes have accompanied the economic transition including large numbers of retirees and commuters to the densely populated Seattle-Tacoma-Olympia metropolitan area (Buttolph et al. 2006). A thriving tourism and recreation sector exists, attracting millions of visitors each year (Headwaters Economics 2012).

The peninsula's changing social and economic context has reignited long-standing political tensions over land use, which date back to 1897 when President Theodore Roosevelt set aside 2.1 million acres of the Olympic rain forest as a national forest reserve to protect the region's forests from commercial logging as well as preserve habitat for Roosevelt elk (Lien 2000; Roloff 1934). Faced with strong opposition by a coalition of homesteaders and logging interests, the federal government reduced the reserve by one-third (Lien 2000). However, a Presidential proclamation established the Mount Olympus National Monument in 1904, placing the core of the ONF off-limits to commercial logging (Roloff 1934). Protection was strengthened in 1933 when the monument's administration shifted from the use-oriented US Forest Service to the protectionist-oriented National Park Service (Lien 2000). It was further enhanced in 1938 when the monument and adjacent national forest lands acquired national park status (Lien 2000). The park is managed primarily as a wilderness reserve where motorized uses are prohibited. Strips along the Queets River and the Pacific coastline and parts of the inland rain forest were added to the park in 1940s and early 1950s (Evans 1983). The expansions were especially contentious as they included acquisitions of private inholdings through condemnation procedures, particularly in and around Lake Quinault and along the Queets River (Evans 1983).

Tensions over whether and how much timber should be harvested from the ONF re-emerged in the 1980s when ecologists identified the negative impacts of the then-prevailing timber management practices on threatened and endangered species, such as the northern spotted owl (Dietrich 1992). The Forest Service and Bureau of Land Management implemented the Northwest Forest Plan in 1994 to address endangered species concerns. This placed most of the land in the ONF into Late Successional Reserves, which had stringent timber harvest restrictions (Charnley 2006). Many residents attribute the Peninsula's economic decline during the 1990s and early twenty-first century to the Northwest Forest Plan, which they perceive as having locked up the ONF's valuable timber resources. The tensions between proponents of minimizing human use on the ONP and ONF and those who would like to see the ONF return to a "working forest" with a much broader range of uses, set the stage for our three case studies.

\section{Methods}

In 2009, ONF managers identified lack of spatial data about the values and uses associated with the peninsula as an impediment 
to assessing the social impacts of its management activities. The Olympic Peninsula HEM project sought to address this through developing a methodology for mapping and analyzing landscape-level forest values and activities (Besser et al. 2014; McLain et al. 2013a). We collected data from local residents during mapping workshops held in eight communities (Fig. 1). The first six workshops took place in 2010. The Forks and Lake Quinault workshops were delayed until fall 2011 for budgetary reasons. A follow-up workshop was also held in 2011 in the Aberdeen/Hoquiam area because of low turnout there in 2010. Participants were assigned to large tables on which we had placed $3 \mathrm{ft}$. $\mathrm{x}$ v3ft (roughly $1 \mathrm{~m} \times 1 \mathrm{~m}$ ) base maps of the Olympic Peninsula (scale $=1: 750,000)$ and completed two mapping exercises. In the first, participants mapped up to five outdoor places that they considered particularly meaningful and assigned up to three values for each place using a reference list of 14 values: Aesthetic, Economic, Environmental Quality, Future, Health, Heritage, Home, Intrinsic, Learning, Recreation, Social, Spiritual, Subsistence, Wilderness (see Besser et al. 2014). Participants indicated a primary value as well as any additional values (unranked). In the second exercise, participants first listed three important outdoor activities they engaged in on the peninsula and then mapped up to five places they visited for each activity.

We used ArcGIS 10.1 to create a geodatabase that combined the digitized meaningful place and activity area boundaries and their associated attributes. We entered demographic data for each individual into an Excel spreadsheet, exported the data into SPSS 18.0, and then joined the Excel dataset to the spatial database using ArcGIS 10.1. We performed the spatial analyses and created maps in ArcGIS 10.1.
Demographic data and non-spatial analysis were conducted in SPSS.

\section{Aggregate Results}

A total of 169 residents participated in the workshops, with 166 producing useable mapped features. Participants mapped 818 meaningful places and 1594 activity areas. Participation rates varied from a low of eight in the first Aberdeen/Hoquiam workshop to a high of 39 in the Lake Quinault workshop (Fig. 1). We combined the data from the eight communities to develop composite density maps that depict the concentration of meaningful places and activity locations for all of the workshop participants. These maps indicate the number of times a particular point on the map fell within the boundaries of a meaningful place or activity site rather than the number of individuals who mapped that location. Meaningful places were most heavily concentrated along the Olympics' western slopes (Fig. 2a), with the heaviest concentrations in the southwestern corners of the ONF and ONP, and on Washington State trust lands. In aggregate, the participants' meaningful places covered most of the peninsula. Outdoor activity sites also were concentrated most heavily along the western slopes of the Olympic Range (Fig. $2 \mathrm{~b}$ ), with smaller areas of high density along the Pacific coast and at several heavily visited and easily accessible sites.

We were surprised that values and activities were most heavily concentrated on the western side of the peninsula since it is the most remote and least populated part of the peninsula. When we disaggregated the data by workshop (Figs 3a-c) it became clear that the Lake Quinault workshop
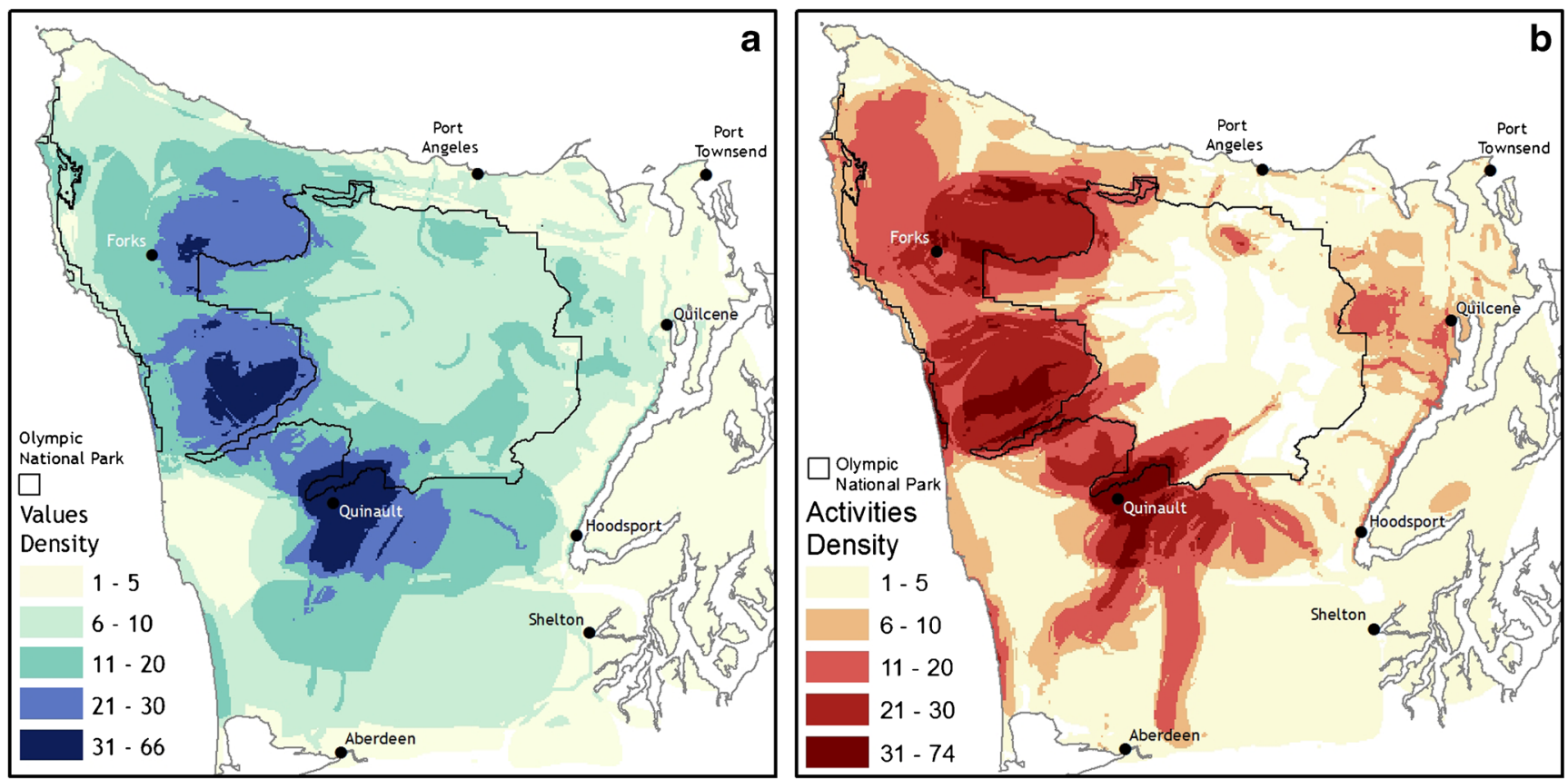

Fig. 2 Density of a values for all workshops, and $\mathbf{b}$ activities for all workshops. Color figure available online 

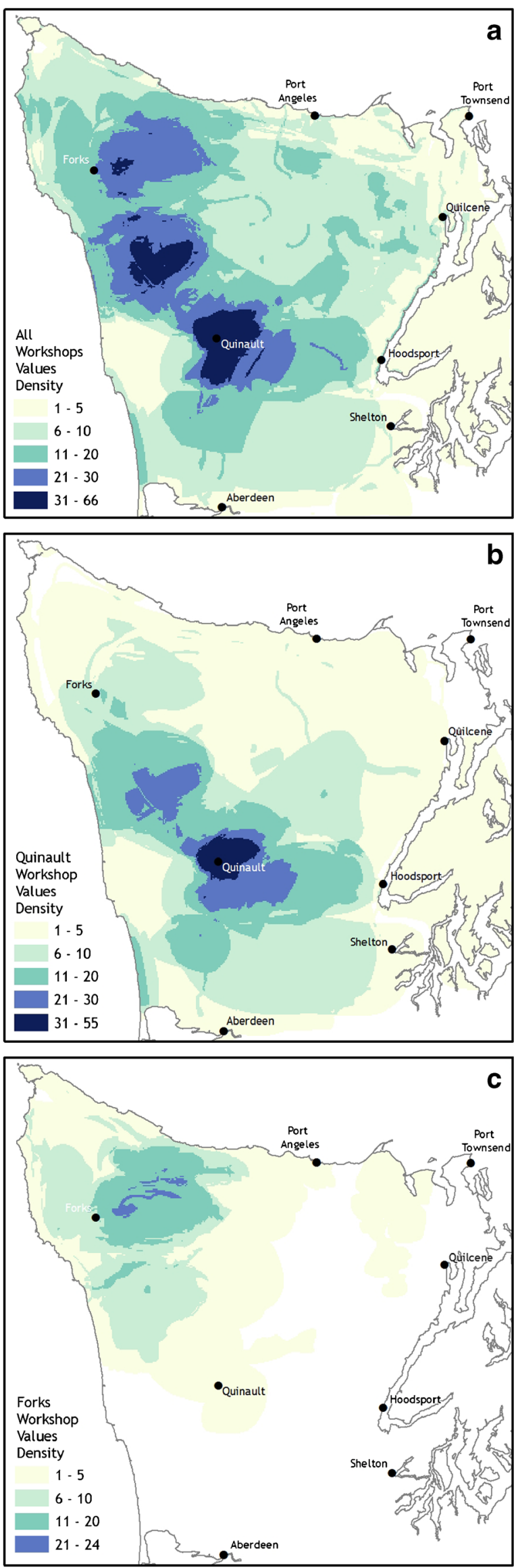

4 Fig. 3 Density of values for a all workshops, b Quinault workshop, and c Forks workshop. Color figure available online

results (Fig. 3b) were largely responsible for the southern part of the hotspot and the Forks workshop results (Fig. 3c) were responsible for the northern part of the hotspot. Our initial thought was that these results reflected the larger number of participants present at the Lake Quinault and Forks workshops, but as we explored further, we realized that the patterns for both workshops were better explained by the relative frequency with which participants mapped specific values and activities that were at least partly attributable to the intense political debates taking place in those communities during 2011.

\section{Case 1 - Fighting Wilderness Expansion}

The longstanding tensions between timber harvesting proponents and conservationists were largely invisible during 2010 when we held the first six workshops. However, by November 2011 when the Lake Quinault and Forks workshops took place, the disagreements over land ownership and use had re-emerged in the public arena. One catalyst was the Wild Olympic Campaign's publication of maps for proposed wilderness areas (http://www.wildolympics.org/forests-andrivers/wilderness) and Wild Scenic Rivers (http://www. wildolympics.org/forests-and-rivers/wild-scenic-rivers/) during summer 2010. The Wild Olympics Campaign was an alliance of local and regional stakeholders supporting proposed federal legislation (Senate Bill 3329 and House of Representatives Bill 5995) known as the Wild Olympics and Wild and Scenic Rivers Act of 2012. The initial draft of the Act was released in fall 2011 and called for roughly 132,000 acres (53,400 ha) of new wilderness in the ONF, 464 miles $(747 \mathrm{~km})$ of Wild and Scenic Rivers, and the acquisition by the ONP through willing seller-willing buyer agreements of up to 20,000 acres (8094 ha) of private land (Headwaters Economics 2012). All three provisions were controversial. Opponents objected to transferring state and private lands to the ONP on the grounds that it would reduce the region's tax base and revenue-generating timberlands (Skinner 2011). The proposed wilderness expansions would have placed parts of the ONF still open to thinning and limited logging operations into a strict no-harvest status. Placing the 19 rivers into 'Wild and Scenic' status would have restricted timber harvest on an additional 11,621 acres (4703 ha) on the ONF and 5200 acres of Washington State trust lands (Underwood and Cross 2012). As more residents became aware of the proposed legislation, opposition grew. By spring 2011, local citizens and businesses had created a group known as the Working Wild Olympics Coalition to stop the Act's passage (Skinner 2011), using the slogan, "Our Olympics are wild enough!" as their rallying cry. 
Opposition to the Wild Olympics Campaign influenced the Lake Quinault workshop results in several ways. It affected local residents' assumptions about the workshop's purpose. Many more people inquired about the Lake Quinault mapping workshop than had contacted us for the previous workshops. In addition, many of the callers assumed that the workshop was part of the Wild Olympics Campaign and openly questioned our motives for creating a map of important areas. The campaign also affected who showed up to map. A number of people we contacted by phone stated that they would like to participate, but that they preferred to stay away out of concerns that Working Wild Olympics Coalition supporters would create a hostile environment. We were concerned enough about whether it would be possible for us to maintain a welcoming and open mapping environment that we considered cancelling the workshop, but ultimately opted to hold it. The leader of the Working Wild Olympics Coalition showed up for the workshop in Lake Quinault, along with numerous supporters of that movement. Although Lake Quinault is located in the least populous part of the peninsula, 39 people attended the workshop. This was almost twice the number of participants in the earlier workshops even though we used the same recruitment tactics.

The tensions surrounding the Wild Olympics Campaign during fall 2011 also influenced how participants interacted with each other and the maps. It was apparent during the Lake Quinault workshop that Coalition supporters were coordinating their mapping activities because participants periodically left their tables to consult with the Coalition leader before marking their maps. Additionally, we observed several participants looking to see what their neighbors were mapping and talking with table partners before marking the exact same places on their maps. This strategic and systematic approach to mapping contrasted markedly with the more idiosyncratic mapping behavior we observed during the 2010 workshops. This difference is readily apparent in the raw data map for one of the tables at the Lake Quinault workshop (Fig. 4), which shows that several participants mapped very large congruent spaces. A practical consequence of multiple people intentionally mapping the exact same places is that densities for those areas on the aggregate maps will be much higher than if people mapped their meaningful places independently.

Tensions over the Wild Olympics may have influenced to some extent what participants mapped, with the values 'economic' and 'home' being far more frequently attached to meaningful places at the Lake Quinault workshop than at the other workshops. For Lake Quinault participants, the value 'economic' was the primary value most frequently assigned to meaningful places (36\%), with 'recreation' second at $21 \%$ (Fig. 5a). In contrast, for the combined dataset, 'recreation' was by far the most frequently assigned primary value for meaningful places (32\%), with 'economic' second at $17 \%$. Additionally, of the places marked with just one value, $32 \%$

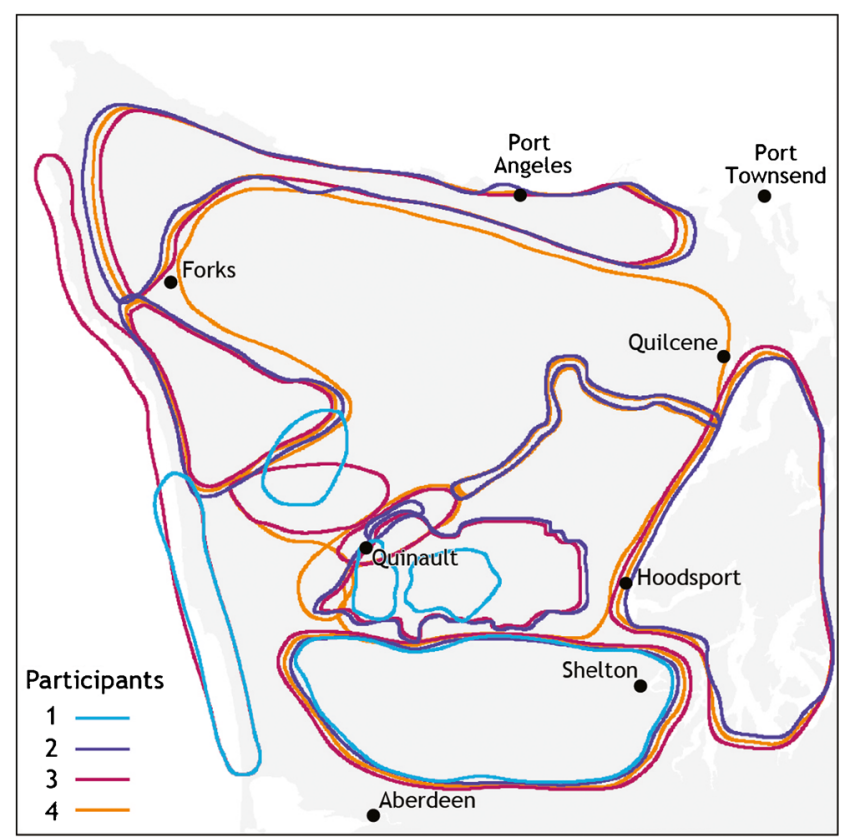

Fig. 4 Raw data from a table at the Lake Quinault workshop. Color figure available online.

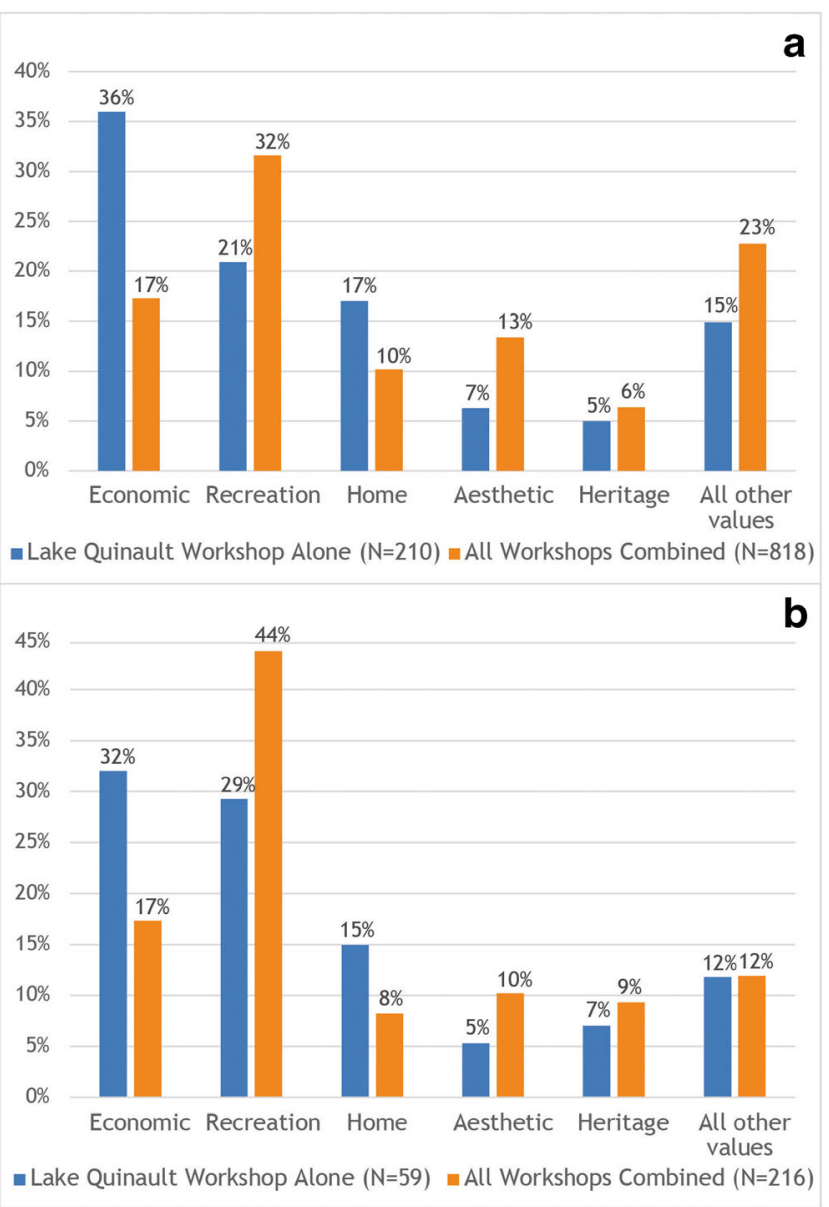

Fig. 5 Percentage of features from the Lake Quinault workshop and aggregate datasets assigned a primary landscape values and $\mathbf{b}$ only one landscape value. Color figure available online 
had 'economic' as their value among Lake Quinault participants compared with only $17 \%$ for all workshops combined (Fig.5b). Moreover, although Lake Quinault participants mapped only $27 \%$ of all places assigned just one value, they mapped $51 \%$ of the sites that had only 'economic' as their value.

The spatial distribution of 'economic' places mapped by Lake Quinault residents contrasted markedly with the patterns of the other workshops (Figs 6a-f). The 'economic' sites mapped by Lake Quinault participants (Fig. 6c) covered virtually the entire Peninsula, including the ONP. Additionally, a large swath along the west side of the Olympics stretching from the area north of Forks to Lake Quinault to the south had a very dense concentration of sites valued for economic reasons. This pattern differed markedly from the map compiled from the other workshops (Fig. 6e), where meaningful places with 'economic' as a primary value covered only half the Peninsula, with the ONP almost entirely excluded. It is noteworthy that when we examined the largest $10 \%$ of the values polygons ( 82 polygons), we found that Quinault workshop participants had drawn $59 \%$ of them. The maps for economic activities (Fig 6b, d, f) show that the hotspot in the aggregate density map (Fig. 6b) is driven by Lake Quinault's results (Fig. 6d). The ONP did not show up as a place where Lake Quinault participants carried out economic activities, reflecting the prohibition on logging in the park.

For many Lake Quinault participants, economic activity meant activities related to the timber industry, such as logging and millwork. Common qualifiers provided by Lake Quinault participants for sites having 'economic' as their primary value included "timber harvesting," "logging," or "timber jobs." Four men sitting at one table and who mapped the same very large area labeled the polygon as "Southwest Olympic National Forest and State Land" and added the following notations respectively: "Logging," "Timber value," "Logging - present and future," and "Economic." Other participants provided longer explanations about their meaningful places. One woman described a place as important because "it provides timber for mills in our local community, providing jobs." Another woman participant who mapped several very large areas as having economic value drew links between logging and livelihoods, stating:

"All the timberland should be considered for some kind of logging and wood cutting. This could provide livelihood for current and future residents in the logging industry and firewood for home. This would allow more residents to stay in Quinault and work here."

Still others emphasized their belief that expanding timber harvesting was the pathway to community prosperity. Quotes similar to the following were attached to a number of sites mapped on the ONF: "The timber is ripe and ready for harvest; there is enough timber here to revive our community."
Lake Quinault participants emphasized that the forest was more than just a place to work; it was also their home. The percentage of meaningful places assigned the primary value of 'home' at the Lake Quinault workshop (17\%) was higher than for the combined dataset (10\%) (Fig. 5). Additionally, of the places marked with just one value, $15 \%$ had 'economic' as their value among Lake Quinault participants compared with only $8 \%$ for all workshops combined (Fig. 5b). Lake Quinault participants mapped more than half the sites with 'home' as their only value.

The density maps for meaningful places having 'home' as their primary value indicated that the Lake Quinault pattern is qualitatively different from the pattern found in the other workshops. For Lake Quinault, places valued as 'home' showed up on the map as a very dense concentration centered around Lake Quinault itself with a gradually less dense concentration radiating eastward to encompass much of the Upper Quinault River valley. In contrast, the other workshops exhibited a more dispersed pattern for places having 'Home' as their primary value with no particularly dense concentrations showing up.

Some of the comments about places marked as important for 'home' by Quinault workshop participants were very brief, and focused on individual connections, such as "My home, property, privacy" and "I feel attached to this valley and to MY land." Others described much deeper connections involving multiple generations or stressed the labor they had invested in the area. One man who mapped the Quinault Valley included the notation, "It's where I've lived my whole life and four generations before me." Another woman said of the place she'd marked with the value 'home,' "It is where our sons were raised and our grandkids visit. We have lived here 30 years and invested our lives in this area." Still others stressed the community connections associated with the places they marked 'home.'

The higher frequency of references to the value 'Home' among Lake Quinault participants, and the dense, relatively extensive concentration of the value 'Home' in the Upper Quinault Valley may be indicative of a desire on the part of Working Wild Olympics Coalition members to communicate the strength of their ties and the length of time their families have held land in the Lake Quinault area as a counterargument to the Wild Olympics proposal, which they perceived as threatening their 'homeland.'

To explore further the notion that the Lake Quinault data might reflect tensions over the proposed Wild Olympic Act, we compared the Lake Quinault values density map with a map showing the boundaries of the areas proposed for wilderness designation. The densest concentrations of meaningful places occurred in the area immediately surrounding Lake Quinault and on private landholdings along the Quinault River, portions of the national park to the north, and portions of the national forest to the southeast. These mapped areas 

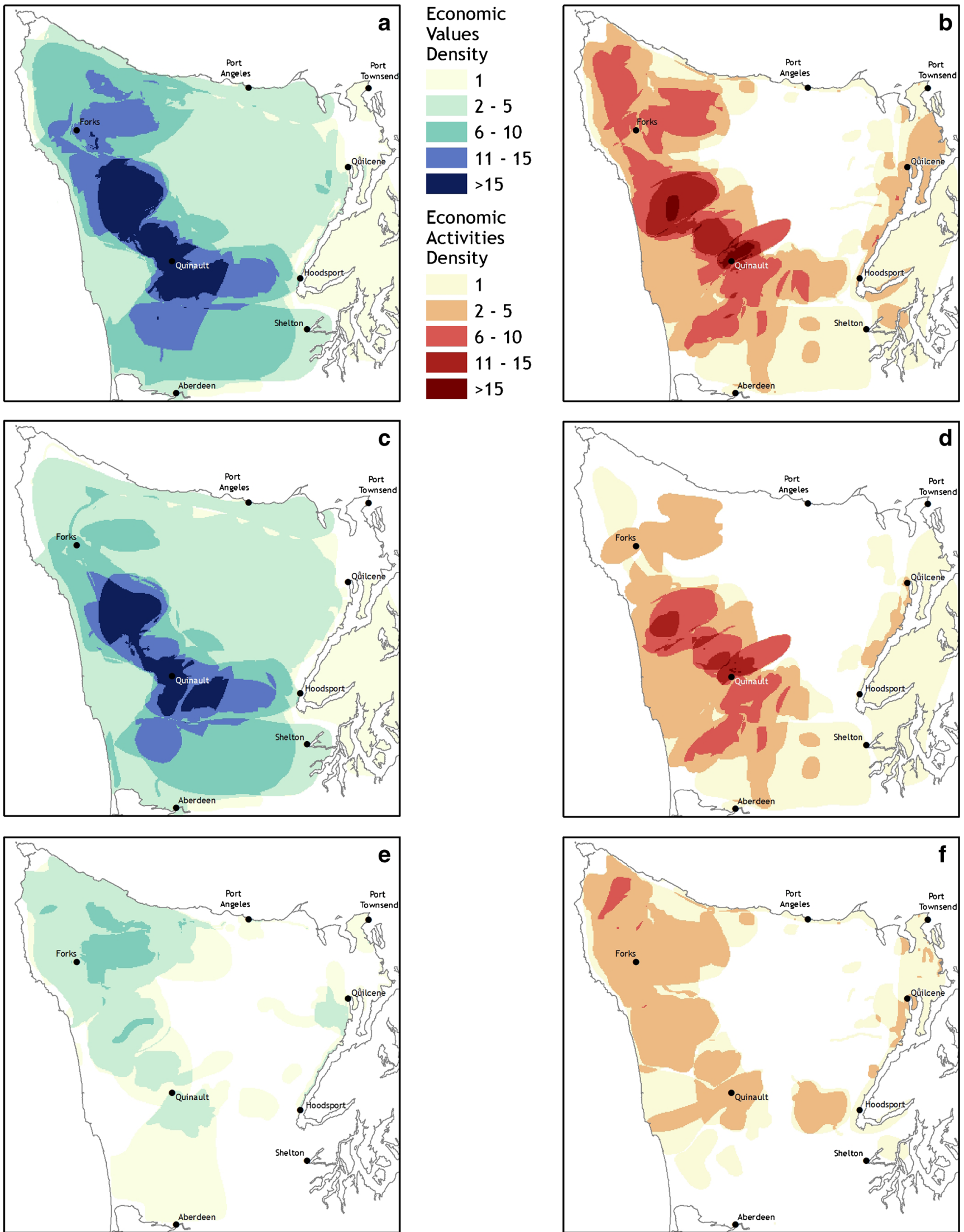

Fig. 6 Density of a economic value for all workshops, $\mathbf{b}$ economic activity for all workshops, $\mathbf{c}$ economic value for the Quinault workshop, $\mathbf{d}$ economic activity for the Quinault workshop, e economic value for all workshops except Quinault, and $\mathbf{f}$ economic activity for all workshops except Quinault. Color figure available online 
coincide with the locations of proposed wilderness areas and Wild and Scenic Rivers in the southwestern part of the peninsula.

We believe that the Lake Quinault mapping process is a variant of what Ramirez-Gomez et al. (2013) called "strategic mapping," and which we label "systematic strategic countermapping' to distinguish it from other forms of strategic mapping we encountered during the HEM project. The Working Wild Olympic Coalition leaders used the workshop to convey their ties to the area being proposed for wilderness expansions. This group recruited participants and provided them with instructions on how to mark the maps, presumably so that they could make a stronger statement about their relationship to this territory. Through the mapping process, Lake Quinault participants made it clear that they had strong concerns about threats to their livelihoods (value 'economic') and personal identities (value 'home'). Our spatial analysis confirmed that the two values 'economic' and 'home' were of greater importance for participants in this workshop relative to the other workshops. We cannot rule out the possibility that the values of livelihood and home would have predominated among the Lake Quinault participants regardless of the Wild Olympics proposal. However, by deconstructing the maps, we provide evidence that a large number of Lake Quinault participants coordinated their mapping efforts to ensure that the resulting maps conveyed the message of the Working Wild Olympics Coalition, "Our Olympics are wild enough."

\section{Case 2 - Defending Motorized Recreation}

In the summer of 2011, a related public debate focused on whether the ONF should establish an off-highway vehicle (OHV) trail system in the Calawah watershed near the town of Forks. The disagreement over the creation of an OHV trails system on the ONF connects back to debates from the 1960s and 1970s as to whether federal forest users should be allowed to operate OHVs in areas not specifically set aside for off-road vehicle use (Adams and McCool 2009). The ONF has roughly two thousand miles of roads, built primarily to provide access to logging sites (USDA-FS 2015). Timber sales financed the roads, and when timber sales dropped after the Northwest Forest Plan's implementation, so too did the agency's road maintenance capacity (USDA-FS 2015). Motorized vehicles are not permitted in wilderness areas, placing large segments of the forest off-limits to motorized vehicles. In 2011, under the ONF Forest Plan, motorized vehicle use was restricted to designated areas and only street-legal vehicles were allowed, a decision which cut off legal access for many OHV users to all roads in the ONF (USDA-FS 2012). However, physical evidence suggested that many OHV riders continued to use roads in the Calawah watershed near the town of Forks, which had long been a popular OHV recreation site for local residents (USDA-FS 2014).
To diffuse the tensions over the lack of OHV access on the national forest, ONF planners proposed to establish an OHV trail system in the Calawah watershed in 2011. The Blue Ribbon Coalition, a national advocacy group for motorized vehicle use on public lands, helped mobilize local OHV riders' participation at community meetings held by the ONF (see BlueRibbon Coalition archive.sharetrails.org/node/ 14990). The meetings were well attended, and gave participants a chance to discuss the potential trail sites (Cook 2011). Many of the participants in the Forks values mapping workshop had attended the OHV community meetings and, as a result, had recent experience mapping their preferences for OHV sites on the ONF.

During outreach for our Forks workshop, municipal officials in Forks informed us that the OHV rider community had circulated the announcement for our mapping workshop. When we arrived in Forks and began to register participants, we found that some had come from as far away as Aberdeen and Port Angeles, even though we had previously held workshops in both communities. Once we started the mapping workshop and circulated around the room, it became clear that at least two table groups contained a high percentage of $\mathrm{OHV}$ riders who talked with each other and worked together to identify places of common interest. In addition, they were more familiar than other participants with the mapping process and seemed to be mapping with a clear sense of intent, suggesting they had communicated with each other prior to the workshop to convey their values and priority activities around motorized recreation.

To understand how OHV interests may have influenced the mapping process, we looked to see how the proportion of 'recreation' values in Forks differed from other workshops. We compared the percentage of mapped features for the Forks workshop alone with mapped features for all eight workshops combined. We looked at primary values assigned to features (Fig. 7a) and at features where only one value was assigned (Fig. 7b). For primary values, we found that for the aggregate dataset, $32 \%$ of features were assigned the primary value of recreation, whereas for the Forks workshop data, the figure was $58 \%$. When we looked at features where only one value was assigned, $44 \%$ of mapped features from all workshops were assigned 'recreation.' However, $74 \%$ of the mapped features in the Forks workshop having only one value were assigned the value of recreation. We conclude that Forks' respondents disproportionately assigned 'recreation' as the primary value for features, and disproportionately mapped places only because of their recreation value.

We also examined the results from the activity site worksheets to identify any differences in the types of recreational activities mapped by Forks workshop participants compared to others. All-terrain vehicle (ATV) or off-highway vehicle (OHV) riding occurred at $43 \%$ of the activity sites mapped in Forks but in only $10 \%$ of all the activity sites 


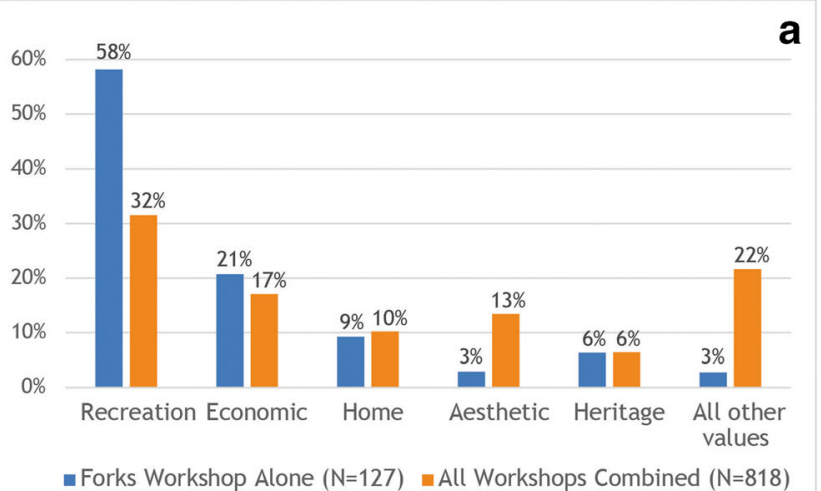

b

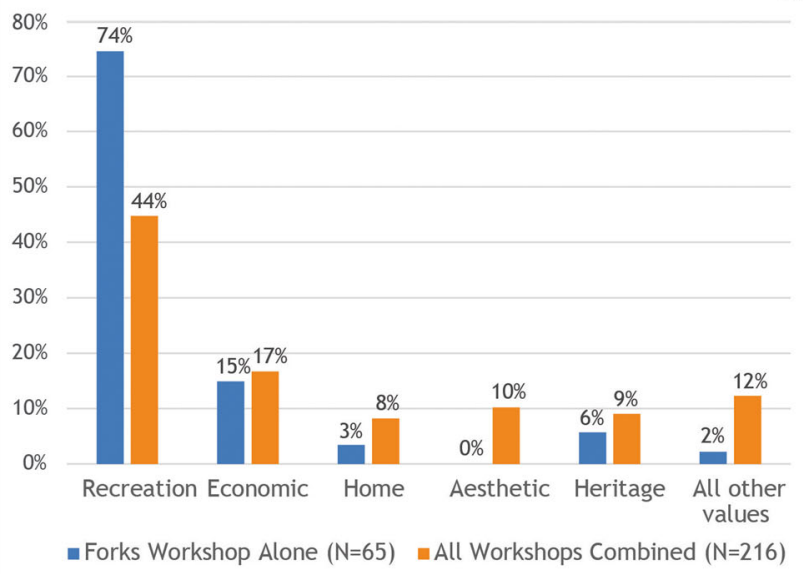

Fig. 7 Percentage of features from the Forks workshop and aggregate datasets assigned a primary landscape values and $\mathbf{b}$ only one landscape value. Color figure available online

mapped. Moreover, fully $75 \%$ of the aggregate dataset's ATV/ OHV activity sites were mapped at the Forks workshop. The aggregate recreation values and motorized recreation maps (Fig 8a, b) show dense concentrations in the northwest quadrant of the Olympic Peninsula near the town of Forks. When these are disaggregated into maps that compare the Forks results (Fig 8c, d) with the results from the other workshops (Fig 8e, f), it becomes clear that the northwestern hotspots in the aggregate maps are attributable primarily to the Forks workshop, which was dominated by motorized recreation, and more specifically OHV use patterns. The hotspots on both maps are located in an area with a dense network of logging roads as well as a number of unauthorized OHV trails. The Forest Service's proposed OHV trails system in the Calawah watershed is situated on the eastern edge of the hotspot, and occupies only a fraction of the area identified as important for ATV/OHV use.

In an open-ended response, one participant described the Calawah watershed as important because it has "many abandoned roads suitable to convert to ATV trails." Another observed that the Forest Service had "closed over 51 miles [82 $\mathrm{km}$ ] of quad riding trails" in the area north and east of Forks and another said of a specific section of the ONF, "This area would make a wonderful quad/motorcycle area (ATV)," adding that it was "close to Port Angeles and Forks." Another participant said of the Calawah-Sitkum watershed: "Provides an awesome place to ride ATVs - contains established trails on old logging grades and roads that have been privately maintained and used for many years!" The individual maps and worksheet comments suggest that participants would like to see a much more extensive set of trails and roads opened up to ATV/OHV use than the 18 miles [19 km] of trails and roads that ONF managers have proposed for the Calawah OHV trail system.

The Forks mapping workshop can be categorized as a case of 'targeted political mapping,' where a particular set of stakeholders - OHV enthusiasts - learned about our mapping workshop and self-organized their attendance, without a clear leader, at our event in advance. Many drove several hours to identify locations on the ONF that best reflected actual and hoped for use of the landscape. The areas identified on the Forks workshop map as being of high value for recreation generally and motorized recreation use specifically, encompass the Calawah-Sitkum watershed, a small portion of which the USFS was considering designating an OHV area. However, and very importantly, the area that the Forks participants mapped was considerably larger. Thus, our community mapping event, designed to gather baseline data about social values and resource uses, became a venue for OHV enthusiasts to map out the area that they wished to see opened up to OHV use.

\section{Counter Example: The Dosewallips Road Closure Controversy}

Although mapping and counter-mapping can be organized and orchestrated by citizen-based organizations and stakeholder groups, individuals or loosely organized interest groups may also use mapping to make statements about how they think forests or parks should be managed. We hypothesized that controversy over the re-opening of the Forest Service's Dosewallips Road might provide another example of strategic mapping. The Dosewallips Road provides access to many trail networks in the ONP and wilderness areas of the ONF. In 2002, the road washed out five miles $(8.1 \mathrm{~km})$ short of the park's eastern boundary, limiting access to popular trailheads, a developed campground, and a park ranger station (USDA-FS 2010). Lack of funds has constrained the agency's ability to repair the road. The USFS and NPS officials have received much negative feedback about the road closure and some local hiking organizations have called for the agencies to reopen the road (Washington Trails Association 2012). In 2010, the USFS and NPS released a joint Final Environmental Assessment evaluating whether and how to repair the road (USDA-FS 2010). The agencies' preferred 

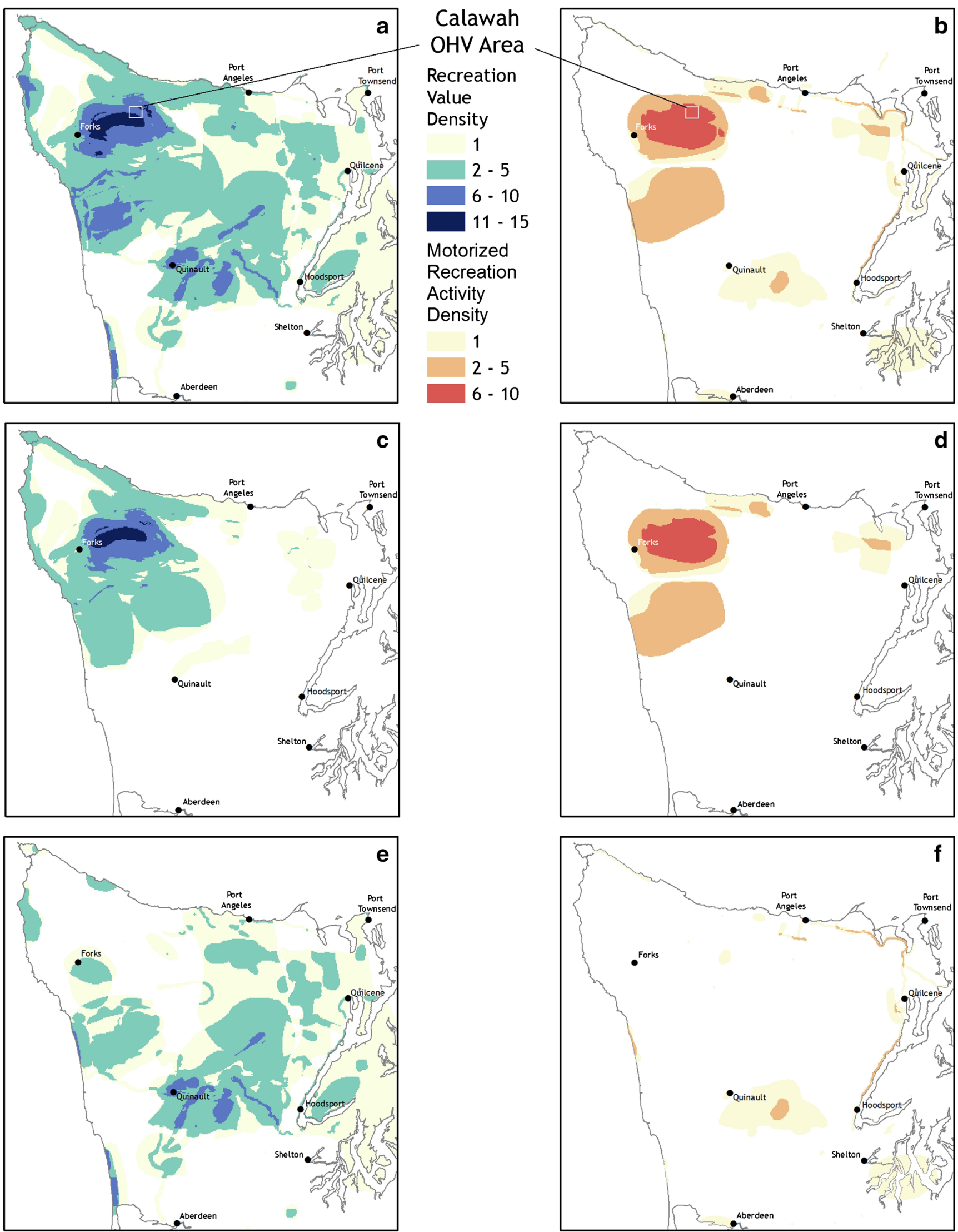
4 Fig. 8 Density of a recreation value for all workshops, b motorized recreation activity for all workshops, $\mathbf{c}$ recreation value for the Forks workshop, d motorized recreation activity for the Forks workshop, e recreation value for all workshops except Forks, and $\mathbf{f}$ motorized recreation activity for all workshops except Forks. Color figure available online

alternative would repair much of the road, but they have deferred making a decision until funds become available. When the workshops took place, the final decision had not yet been made, nor was one imminent. Nonetheless, local hikers could have used the mapping workshops, particularly those held on the eastern side of the Peninsula, to make a statement about their desire for the road to be re-opened (or left closed). During the mapping workshops, several individuals asked questions about whether they could map places that they no longer had access to, but wanted to see re-opened, with the Dosewallips among the sites specifically mentioned. Others commented that they intended to mark the Dosewallips trailheads to send a message to the USFS and NPS that the washed-out road inhibits their ability to access valued places.

To see whether the tensions over the Dosewallips Road generated organized strategic mapping behavior similar to that which occurred in Lake Quinault and Forks, we looked at mapped places and analyzed the qualitative data from workshops that took place in the Dosewallips region. This analysis showed that 14 meaningful places were located within the Dosewallips River valley, and an additional 18 included the Dosewallips as part of larger areas that they mapped. However, the washout was not mentioned in any meaningful places comments. For activity sites, 22 were mapped specifically within the Dosewallips River valley and another 27 included the Dosewallips as part of a broader mapped area. However, only one person described the road washout as a deterrent to access. Whether others mapped sites within the Dosewallips River valley that are no longer easily accessible as a way of making a political statement about the washout is unknown. However, the maps of meaningful places and activity sites in the Dosewallips River valley did not reveal the dense concentrations for values and activities visible in the Lake Quinault and Forks data that would be indicative of an organized effort to map in ways that would make the Dosewallips road closure issue visible on the map.

\section{Discussion}

This study has shown that local resource politics can significantly affect who participates in landscape-values mapping projects as well as how and what they choose to map, all of which have implications for whose values and what patterns of values show up on the resulting maps (McLain et al. 2013a). Through examining the intersection between place theory's concepts of place attachment and place identity (Proschansky et al. 1983; Twigger-Ross and Uzell 1996) and critical cartography's concept of counter-mapping (Peluso 1995; Wood 2009), we identified circumstances under which many organized groups are likely to intentionally use landscape-values mapping as a discursive strategy to further particular place meanings and visions of how landscapes should be managed. Our study provides a model of how researchers and practitioners can systematically tease out the impacts of local resource politics on map outcomes. Additionally, below, we provide a set of guiding questions that can inform the selection of mapping strategies so as to more effectively account for the impacts of resource politics on mapping processes.

The three case studies included here describe a spectrum of politically motivated mapping approaches ranging from the highly organized strategic mapping at Lake Quinault to the targeted but less deliberately orchestrated mapping in Forks to what we presume to be an isolated case of individualized political mapping at the Quilcene workshop. Drawing on understandings from place theory of the roles that place attachment and identity play in catalyzing collective action in defense of particular place meanings (Devine-Wright 2009; Hurley and Walker 2004), we speculate that organized strategic mapping may be more likely when a group feels that their livelihoods and social identity are at stake, when conflict is overt, and when participants see mapping as an opportunity to influence resource-use decisions (Ramirez-Gomez et al. 2013). An interesting question is why the Wild Olympics Campaign supporters did not show up to map in the same organized fashion as the Working Wild Olympics Coalition supporters. One plausible explanation is that they already had a map that adequately represented their political goals, and therefore had no compelling reason to make an additional statement. Their absence in the Lake Quinault workshop supports the notion that politically-driven mapping may be more likely when groups or individuals feel disempowered (Peluso 1995) or when their livelihoods and identities are threatened (Devine-Wright 2009).

Alternatively, the Wild Olympics supporters may have been among the prospective participants who were unwilling to attend the workshop because of fears the meeting would turn hostile. Regardless of why Wild Olympic Campaign supporters chose not to participate as an organized group, the outcome was the same - their values were less visible on the resulting map. Whether such silences on the map can or should be addressed will depend upon the mapping project goals and resources available, but at a minimum it is important to recognize that those silences exist when interpreting the maps (Harley 2009).

The Forks and Quinault participants were more organized in their selection of values and activities than participants in the eastside workshops who might have had strong feelings 
about the Dosewallips road closure. One possible explanation may be that values and activities in the Dosewallips area were heavily oriented toward hiking, and those who engage in them have a wider selection of alternative sites to choose from. Places to hike are less scarce than logging sites or legally accessible OHV routes on the Olympic Peninsula. The lack of economic alternatives may be particularly salient in circumstances where identities and economic livelihoods are tightly bound up (Marshall 2011). An alternative explanation may be that the closure of the Dosewallips road may be more of an issue for visitors than for residents, and since visitors weren't included in the workshops, their concerns would not show up on the map. Another possible explanation for the differences in mapping around these three issues may be the political saliency of the issues. The Forks and Quinault workshops took place when two long-standing debates over public forest management acquired new relevance because of imminent legislation or management decisions, whereas no near-term decisions were expected for the Dosewallips Road. The notion that political saliency matters for participation is supported by Mitchell et al.'s (1997) typology for distinguishing stakeholders from non-stakeholders on an issue. In developing their typology, they identified urgency of the issue to the affected group as one of three key distinguishing criteria of stakeholders (the other two are stakeholder power and feelings that decision-making processes are legitimate).

The Forks and Lake Quinault participants appeared to differ in their motivation for participating in the mapping workshops and the way in which they chose to engage in public debates. The Forks participants had previously discussed the plans for the proposed OHV use area with Forest Service officials and did not express dissatisfaction about the way those meetings had unfolded. In Quinault, however, participants expressed very strong dissatisfaction with the process that led to the creation of the Wild Olympics map. The Working Wild Olympics Coalition members who contacted us about the values mapping workshop felt that they hadn't been included or else their input had not been listened to during the initial planning phases of the Wild Olympics proposal. This may have prompted their use of an overtly strategic mapping approach during the workshop. We use the term systematic strategic mapping to describe this style of mapping, which we believe differs fundamentally from the way in which participants in the other workshops mapped. The locations they mapped, the style in which they mapped, and the comments they included on the worksheets suggest that many of the Lake Quinault participants saw the workshop as an opportunity to create a counter-map to the Wild Olympics map depicting the Olympic Peninsula as a working forest rather than a wilderness. Drawing on Mitchell et al.'s (1997) stakeholder typology, we speculate that the Forks participants were responding to a planning process they considered legitimate whereas the Lake Quinault participants were responding to a planning process that they felt lacked legitimacy.

The influence of place attachment, identity, and discursive strategies on mapping outcomes has implications for landscape-values mapping/PPGIS project design strategies. Recognizing that landscape-values mapping/PPGIS project goals vary widely (McLain et al. 2013a, b), we draw on our experiences and the critical cartography/GIS literature to provide guidance for researchers seeking to capture a broad range of landscape-values. Our three cases suggest that asking the following questions early on in the design phase can help researchers and practitioners identify mapping strategies appropriate for the local political context.

- Are there groups in the area with a strong sense of disempowerment related to decision-making about natural resources?

- Are there groups whose livelihoods are threatened by recent or prospective natural resource policies or management decisions?

- Are there highly controversial policies or decisions currently being debated?

- Are there groups in the area who have very strong feelings of attachment to places likely to be affected by those policies and decisions currently under debate?

- If upcoming decisions will affect places where individuals or groups engage in activities that they consider important to their well-being or livelihoods, are there alternative places that can fulfill those same functions?

If the answer to all or most of these questions is yes, it is reasonable to assume that the incentives for strategic mapping are strong, especially if prospective participants believe that the mapping has potential to affect the outcomes of upcoming controversial decisions. Under such circumstances, we hypothesize that targeted strategic mapping is more likely if participants perceive decision processes to be legitimate and systematically organized strategic mapping is more likely if they are perceived as lacking legitimacy.

One strategy for reducing the likelihood or effects of strategic mapping is the use of sampling strategies such as random sampling or invitation-only sampling that result in the recruitment of a broad cross-section of the affected population. However, random sampling may not always be feasible or affordable. A second strategy is to use data collection approaches that minimize opportunities for coordination between individuals, such as one-on-one mapping sessions or surveys. However, if the project goals include fostering dialogue or trust-building, then group-based activities such as community workshops or focus groups are more appropriate. For group mapping events, if the likelihood of strategic mapping behavior is high, it is advisable to use a purposive 
sampling strategy and avoid reliance on participant self-selection. However, it is also important to recognize that the occurrence of strategic mapping, whether highly organized as at Lake Quinault, more targeted as in Forks, or individualized as for the Dosewallips Road, does not invalidate the data, but rather can help planners identify areas where participants have particularly strong attachments or concerns.

As Harley (2009) points out, maps are inherently reflective of the political contexts in which they are created. Moreover, political contexts are dynamic and conflicts, such as the one surrounding the Wild Olympics, may emerge after projects are already underway and difficult to modify. In our case, for example, even though we knew that it was likely that the Lake Quinault workshop excluded important elements of the local population, we did not have the resources to organize other mapping events that might have remedied those exclusions. In such situations, it is important to tease out the impacts of resource politics when analyzing the data and explicitly describe those impacts when interpreting the data.

\section{Conclusion}

Over the past decade, landscape-values mapping has become increasingly accepted as a tool for collecting spatial data about the values that individuals place on terrestrial and marine ecosystems. However, individuals have any number of places that are important to them, and, in many cases, associate multiple values with each place (Cerveny et al. 2017). Our deconstruction of the Olympic Peninsula HEM map illustrates that who shows up to map, which places participants choose to map, and the values that they choose to include on the maps, are all likely to be influenced by on-going public debates over natural resources. As a result, credible interpretations of landscapevalues maps require delving into the story behind the maps and considering how that story affects what is shown or not shown on the map.

Acknowledgements We thank Diane Besser for assistance throughout the project, Laysa Rodriguez and Lee Greer for workshop support, and Corinna Kimball-Brown, Alexa Todd, and Stephanie Rohdy for GIS analysis. We thank the many community groups who assisted with outreach.

\section{Compliance with Ethical Standards}

Funding The project was funded by USDA-Forest Service, Pacific Northwest Research Station under Joint Venture Agreement 08-JV11261985-177 with an in-kind match from the Institute for Culture and Ecology, and by US Forest Service, PNW Research Station Agreement \#10-CR-11261975-080 with Portland State University.

Conflict of Interest The authors declare that they have no conflict of interest.

\section{References}

Adams J. C., and McCool S. F. (2009). Finite recreation opportunities: The Forest Service, the Bureau of Land Management, and off-road vehicle management. Natural Resources Journal 49: 45-116.

Besser D. T., McLain R., Cerveny L. K., Biedenweg K., and Banis D. (2014). Mapping landscape-values: Issues, challenges and lessons learned from fieldwork on the Olympic peninsula, Washington. Environmental Practice 16(2): 138-150.

Bethel M. B., Brien L. F., Danielson E. J., Laska S. B., Troutman J. P., Boshart W. M., Giardano M. J., and Phillips M. A. (2011). Blending geospatial technology and traditional ecological knowledge to enhance restoration decision-support processes in coastal Louisiana. Journal of Coastal Research 27(3): 555-571.

Biedenweg K., Cerveny L., and McLain R. (2014). Values mapping with Latino forest users: Contributing to the dialogue on multiple land use conflict management. Practicing Anthropology 36(1): 33-37.

Brown G. (2005). Mapping spatial attributes in survey research for natural resource management: Methods and applications. Society and Natural Resources 18(1): 17-39.

Brown G. G., and Reed P. (2009). Public participation GIS: A new method for use in national forest planning. Forest Science 55(2): 166-182.

Brown G., and Kyätta M. (2014). Key issues and research priorities for public participation GIS (PPGIS): A synthesis based on empirical research. Applied Geography 46: 122-136.

Brown G., Kelly M., and Whitall D. (2014). Which "public"? Sampling effects in public participation GIS (PPGIS) and volunteered geographic information (VGI) systems for public lands management. Journal of Environmental Planning and Management 57(2): 190-214.

Buttolph, L. P., Kay, W. charnley, S., Moseley, C. and Donoghue, E. M. (2006). Northwest Forest plan-The first 10 years (1994-2003): Socioeconomic monitoring of the Olympic National Forest and three local communities. Pacific northwest general technical report 679. USDA-Forest Service, Pacific northwest Research Station: Portland, Oregon.

Carolan M. S. (2009). "this is not a biodiversity hotspot": The power of maps and other images in the environmental sciences. Society and Natural Resources 22(3): 278-286.

Cerveny L. K., Biedenweg K., and McLain R. (2017). Mapping meaningful places on Washington's Olympic peninsula: Toward a deeper understanding of landscape-values. Environmental Management. doi:10.1007/s00267-017-0900-x.

Chapin M., Lamb Z., and Threlkeld B. (2005). Mapping indigenous lands. Annual Review of Anthropology 34: 619-638.

Charnley, S. (2006). Socioeconomic monitoring results. Vol. II: timber and non- timber resources. In: Charnley, S., tech. coord. Northwest Forest Plan - the first 10 years (1994-2003): Socioeconomic monitoring results. Pacific Northwest General Technical Report 649. USDA-Forest Service, Pacific Northwest Research Station, Portland, Oregon.

Cheng A. S., Kruger L. E., and Daniels S. E. (2003). "place" as an integrating concept in natural resource politics: Propositions for a social science research agenda. Society and Natural Resources 16 : 87-104.

Cook C. (2011). Packed house offered chance at creating three quad trails. In Forks Forum Available from: http://forksforum.com/news/article. exm/2011-09-02_packed_house_offered_chance_at_creating three_quad_trails.

Dark A. (1997). Landscape and politics on the Olympic peninsula: Social agendas and contested practices in scientific forestry. Journal of Political Ecology 4: 1-25.

Devine-Wright P. (2009). Rethinking NIMBYism: The role of place attachment and place identity in explaining place-protective action. Journal of Community and Applied Social Psychology 19: 426441. 
Dietrich W. (1992). The final Forest: The battle for the last great trees of the Pacific northwest, The Penguin Group, New York.

Evans G. E. H. (1983). Historic resource study 1983 Olympic National Park, Cultural Resources Division, Recreation Resources and Professional Services. National Park Service, Department of the Interior, Pacific Northwest Region Seattle, WA Available from: https://www.nps.gov/parkhistory/online_books/olym/hrs/contents. $\mathrm{htm}$.

Gunderson K., and Watson A. (2007). Understanding place meanings on the bitterroot National Forest, Montana. Society and Natural Resources 20(8): 705-721.

Harley J. B. (2009). Maps, knowledge and power. In Henderson G., and Waterstone M. (eds.), Geographic thought: A praxis perspective, Routledge, New York, pp. 129-148.

Harley J. B. (1989). Deconstructing the map. Cartographica 26(2): 1-20.

Harris L. M., and Hazen H. D. (2006). Power of maps: (counter) mapping for conservation. ACME: An International Journal for Critical Applied Geographies 4(1): 99-130.

Headwaters Economics (2012). The economy of the Olympic peninsula and potential impacts of the draft congressional watershed conservation proposal, Bozeman, MT, Headwaters Economics Available from: http://headwaterseconomics.org/land/reports/olympicpeninsula.

Hurley P., and Walker P. (2004). Whose vision? Conspiracy theory and land-use planning in Nevada County, CA. Environment and Planning A 36(9): 1529-1547.

Kemmis D. (1990). Communities and the politics of place, University of Oklahoma Press, Norman, Oklahoma.

Lien C. (2000). Olympic battleground: The power politics of timber preservation, The Mountaineers Books, Seattle, Washington.

Marshall N. A. (2011). Assessing resource dependency on the rangelands as a measure of climate sensitivity. Society and Natural Resources 24(10): 1105-1115.

McLain R., Cerveny L., Besser D., Banis D., Todd A., Rohdy S., and Kimball-Brown C. (2013a). Mapping human-environment connections on the Olympic peninsula: An atlas of landscape-values, Occasional Papers in Geography No. 7, Portland State University, Portland, Oregon.

McLain R., Poe M., Biedenweg K., Cerveny L., Besser D., and Blahna D. (2013b). Making sense of human ecology mapping: An overview of approaches to integrating socio-spatial data into environmental planning. Human Ecology 41(5): 651-665.

Mitchell R. K., Agle B. R., and Wood D. J. (1997). Toward a theory of stakeholder identification and salience: Defining the principle of who and what really counts. The Academy of Management Review 22(4): 853-886.

Norheim R. A. (2001). How institutional cultures affect results: Comparing two old-growth forest mapping projects. Cartographica 38(3/4): $35-52$

Peluso N. (1995). Whose woods are these? Counter-mapping forest territories in Kalimantan. Indonesia Antipode 27: 383-406.

Perkins C. (2003). Cartography: Mapping theory. Progress in Human Geography 27(3): 341-351.

Pocewicz A., and Nielson-Pincus M. (2013). Preferences of Wyoming residents for siting of energy and residential development. Applied Geography 43: 45-55.

Proctor J. (1995). Whose nature? The contested moral terrain of ancient forests. In Cronon W. (ed.), Uncommon ground: Toward reinventing nature, WW Norton and Company, New York, pp. 269-297.

Proshansky H., Fabian H. K., and Kaminoff R. (1983). Place identity: Physical world socialisation of the self. Journal of Environmental Psychology 3: 57-83.

Ramirez-Gomez S. O. I., Brown G. G., and Tjon Sie Fat A. (2013). Participatory mapping with indigenous communities for conservation: Challenges and lessons from Suriname. Electronic Journal of Information System in Developing Countries 58: 1-22.
Ramirez-Gomez S. O. I., Brown G., Verweij P. A., and Boot R. (2016). Participatory mapping to identify indigenous community use zones: Implications for conservation planning in southern Suriname. Journal for Nature Conservation 29: 69-78.

Raymond C. M., Bryan B. A., MacDonald D. H., Cast A., Strathearn S., Grandgirard A., and Kalivas T. (2009). Mapping community values for natural capital and ecosystem services. Ecological Economics 68: 1301-1315.

Roloff C. E. (1934). The mount Olympus National Monument. The Washington Historical Quarterly 25(3): 214-228.

Rundstrom R. A. (1990). A cultural interpretation of Inuit map accuracy. Geographical Review 80(2): 155-168.

Sack R. D. (1992). Place, modernity and the Consumer's world, JohnsHopkins University Press, Baltimore, Maryland.

Skinner D. (2011). The wild wild wet: Going behind the Cascade curtain of Washington state to the fabulously green Olympic peninsula. Range Magazine Fall: 14-21.

Sherrouse B. C., Clement J. M., and Semmens D. J. (2011). A GIS application for assessing, mapping, and quantifying the social values of ecosystem services. Applied Geography 31: 748-760.

Stokowski P. A. (2002). Languages of place and discourses of power: Constructing new senses of place. Journal of Leisure Research 34: 368-382.

Tipa G., and Nelson K. (2008). Introducing cultural opportunities: A framework for incorporating cultural perspectives in contemporary resource management. Journal of Environmental Policy and Planning 10(4): 313-337.

Tuan Y. F. (1977). Space and place: The perspective of experience, Edward Arnold Ltd, London.

Twigger D. (1999). Nature, work and 'the environment': Contesting sentiments and identities in the southwest of western Australia. Australian Journal of Anthropology 10(2): 163-176.

Twigger-Ross C. L., and Uzzell D. (1996). Place and identity processes. Journal of Environmental Psychology 16: 205-220.

Underwood D., and Cross J. (2012). Analysis of the Wild Olympics Wilderness and Wild and Scenic Rivers Act of 2012: Economic impacts and opportunities. Port of Port Angeles, Clallam County and the City of Forks: Clallam County, Washington.

United States Census Bureau (2010). QuickFacts. In Clallam County, Grays Harbor county, Jefferson County, and Mason County, State, Washington.

United States Department of Agriculture, Forest Service (USDA-FS) (2010). Summary, Final environmental impact statement: Dosewallips Road washout project, Hood Canal Ranger District and Olympic National Park. Jefferson County, Washington.

USDA-FS. (2012). Scoping letter for the Calawah OHV project. April 19, 2012. Pacific Range District, Olympic National Forest: Forks, Washington. On file with lead author.

USDA-FS. (2014). Environmental assessment: Calawah watershed road decommissioning project, Clallam County Washington, Pacific Ranger District, Olympic National Forest.

USDA_FS. (2015). Travel analysis report, Olympic National Forest, Olympia, Washington Available from: http://www.fs.usda.gov/ main/olympic/landmanagement/planning\#TAR.

Walker P., and Fortmann L. (2003). Whose landscape? A political ecology of the 'exurban' sierra. Cultural Geographies 10(4): 469-491.

Washington Trails Association. (2012). State of access: the future of roads on public lands. Available from: http://www.wta.org/action/roadaccess-to-trails.

Wood D. (1992). How maps work. Cartographica 29 66-74.

Wood, D., with Fels, J. and Krygier, J. (2009). Rethinking the power of maps. The Guildford Press, New York.

Yung L., Freimund W. A., and Belsky J. M. (2003). The politics of place: Understanding meaning, common ground, and political difference on the Rocky Mountain front. Forest Science 49(6): 855-866. 